\title{
Stanisław Jędrzejewski. 2010. Radiofonia publiczna w Europie w erze cyfrowej. Kraków: Universitas, ss. 283
}

T/ążka Stanisława Jędrzejewskiego Radiofonia publiczna w Europie w erze cyUrowej, która ukazała się nakładem krakowskiej oficyny Universitas (2010), to namysł nad rolą radia i jego potencjałem społecznym we współczesnym świecie. Chociaż media, systemy medialne czy kwestie dotyczące telewizji i nowych mediów (ze szczególnym uwzględnieniem Internetu) są relatywnie częstymi tematami pojawiającymi się w publikacjach wydawanych w języku polskim, to samo radio jako osobny temat $w$ dociekaniach badaczy mediów pojawia się dość rzadko. Praca Stanisława Jędrzejewskiego, wybitnego eksperta w dziedzinie radia, współpracującego z Polskim Radiem SA czy European Broadcasting Union, wypełnia pewną lukę na ryku wydawniczym. Kolejne rozdziały to nie wprowadzenie w historię tego medium, lecz ukazanie problemu, jakim jest radiofonia publiczna, również ta w Polsce, a więc to radiofonia - wobec demokracji, komunikowania politycznego, finansowania radia oraz, co szczególnie istotne, radio wobec nowych technologii. Podstawę, na której jest zbudowana całość wywodu, stanowią rozważania na temat modelu publicznych mediów w społeczeństwie demokratycznym. To media właśnie są w tego typu społeczeństwach elementem systemu, który nie tylko pełni funkcję informacyjną, ale także - a może przede wszystkim - jest siłą kreującą postawy i opinię publiczną. Co ważne, dotyczy to w takim samym stopniu bieżących wydarzeń politycznych i społecznych co ekonomicznych i konsumenckich. Kontrola państwowa nad mediami w ogólności (w tym nad radiem) w systemie demokratycznym jest zasadniczo nieefektywna, media zaś stanowią część „elektronicznej sfery publicznej”: kreują opinię publiczną, pośredniczą pomiędzy aktorami generującymi informacje a odbiorcami owej informacji oraz promują określone postawy i kreują zainteresowanie określonymi kwestiami jako tymi, które wydają się istotne z systemowego punktu widzenia. Tym samym pojawia się tu pytanie o kwestie mediów jako tych elementów systemu, które nie tylko pośredniczą w przekazywaniu treści, ale także kreują owe treści, eksponując pewne informacje, pomijając inne czy ukazując określone tropy interpretacyjne zawarte w materiale dziennikarskim. Te ostatnie mają na celu pokierowanie odbiorcą tak, by w relatywnie bezkonfliktowy sposób przyjmował on za swój punkt widzenia właściciela, wydawcy i dziennikarza danego tytułu informacyjnego. 
O ile kwestia związana z obiektywizmem mediów i radia nie ma tak dużego znaczenia w przypadku nadawców komercyjnych (realizują one wizję programu i światopoglądu właściciela czy dziennikarza, co jest związane z kwestiami własności i finansowania, a dana stacja jest oczywistym elementem gry rynkowej i jest poddawana zasadom wolnej konkurencji), o tyle świadomość kreowania opinii i przekazywania w programach określonego światopoglądu jest w przypadku nadawcy publicznego kwestią, która dyskutowana jest w zasadzie od momentu zaistnienia tego modelu nadawczego. Podejście umiarkowanie liberalne, łączące uniwersalizm z profilowaniem oferty (zawierające programy wyspecjalizowane, dla młodzieży, stacje regionalne), wydaje się tym, które w najbardziej wyważony sposób spełnia liczne postulaty i oczekiwania rynkowe i odbiorcze $w$ relacji do systemu polityczno-społecznego danego kraju, a jednocześnie jest relatywnie elastyczne i ma największy potencjał w pełnieniu podstawowych funkcji, jakie nadawca publiczny powinien wypełniać.

Podstawowe pytanie, jakie zadaje sobie autor niniejszej publikacji, to sposób, w jaki radio musi odnaleźć się w rzeczywistości determinowanej technologicznie przez nowe media, zwłaszcza przez Internet w wersji Web 2.0. Z jednej bowiem strony mamy do czynienia z zanikiem tradycyjnego sposobu konsumpcji mediów, w którym radio $w$ dotychczasowej formie pełniło istotne funkcje społeczne, zwłaszcza w odniesieniu do gospodarstw domowych, z drugiej zaś strony, nadawcy radiowi stają przed koniecznością znalezienia sposobu na przekonanie odbiorcy do własnej oferty w sytuacji ekspansji nowych mediów. Innymi słowy, radio musi sobie poradzić $z$ sytuacją, w której na rynku medialnym pojawia się nowy konkurent - Internet: atrakcyjny, łatwy w obsłudze i tani, co sprawia, że szukanie coraz to nowych nisz i środowisk odbiorczych zyskuje nowy wymiar. Co ważne, dla nadawców Internet stanowi uniwersalną platformę medialną, na której znajduje się miejsce i dla radia, i dla prasy, i dla telewizji. Wszystkie bowiem tradycyjne media przechodzą procesy transformacyjne, związane z cyfryzacją oraz zmianą mentalności odbiorcy, dla którego Internet staje się powoli pierwotnym źródłem rozrywki, zdobywania wiedzy czy pozyskiwania bieżących informacji. Jest to związane z procesem, na który autor zwraca baczną uwagę, nowego sposobu dystrybucji władzy w mediach, gdzie nowe media, zwłaszcza Internet, stanowią pole, na którym rozgrywana jest swoista rywalizacja - nie tylko o odbiorcę w kontekście funkcjonowania mediów jako takich, ale także o możliwość kreowania nowych sposobów wpływania na owego odbiorcę (czytelnika, widza, a dla radia - słuchacza). Oznacza to nowe procesy kształtowania opinii publicznej przez media i dziennikarzy oraz - co dla kultury 2.0 kluczowe - nowego typu aktu komunikacji i dekodowania informacji, $w$ którym odbiorca przestaje być pasywnym elementem aktu, a staje się osobą kreującą znaczenia i poniekąd - sam staje się nadawcą. W przypadku mediów tradycyjnych sytuacja taka nie mogła mieć miejsca - przepływ informacji i znaczeń zasadniczo był jednostronny i wymuszał okre- 
ślone postawy zarówno ze strony nadawcy, jak i odbiorcy w akcie komunikacji transmitowanym za pomocą masowych mediów. (Trzeba tu pominąć szczególny przypadek, jakim były/są reżimy niedemokratyczne, w których relacja nadawca-odbiorca jest ściśle i sztywno określona i, co więcej, dystrybucja informacji oraz zachowania nadawców-dziennikarzy podlegają ścisłej kontroli państwowej).

Szczególnego znaczenia nabierają owe pytania w odniesieniu do nadawców publicznych. Po gruntownych przemianach, jakie ten sektor radiowy przechodził na świecie na przełomie lat 80. i 90. XX wieku (w wielu krajach Europy zniesiono monopol państwowy na nadawanie radiowe i uwolniono mechanizmy rynkowe, jak choćby w przechodzącej proces transformacji ustrojowej Polsce), wytworzyła się swoista przestrzeń rywalizacji nadawców publicznych z prywatnymi, a więc konieczność wyważenia relacji między utrzymaniem udziałów w rynku w warunkach konkurencji, realizowania misji nadawcy cieszącego się statusem „nadawcy publicznego" oraz konkurowania z komercyjnymi stacjami, co pociągało za sobą konieczność uatrakcyjniania ramówki (konsekwencją czego była często pauperyzacja treści w nadawanych programach), emitowania reklam i wprowadzania treści, na które występuje społeczne zapotrzebowanie.

Najbardziej interesujący poznawczo wydaje się rozdział piąty książki, w którym autor zastanawia się nad perspektywami rozwoju tak specyficznej instytucji, jaką jest radio. Wraz z rozwojem technologii pojawiają się bowiem nowe konteksty nie tylko w wymiarze strukturalnym i organizacyjnym, ale także kulturowym. Nowoczesne technologie i swego rodzaju uwikłanie radia w Internet i procesy cyfryzacji są namacalnymi wymiarami, które trzeba brać pod uwagę przy projektowaniu oferty radiowej z jej całą specyfiką. Jednak należy uznać, że to sfera kulturowa będzie tą, która na radio oddziała najbardziej w dłuższej perspektywie - przemiany związane z upowszechnianiem się nowych mediów to wszak nie tylko technologia. To również styl życia odbiorców informacji i nowy sposób, w jaki szukają, przetwarzają i konsumują oni informację oraz rozrywkę w wymiarze całościowym. Naturalny zatem jest ruch nadawców radiowych, na który zwraca uwagę Jędrzejewski, polegający na "zasiedlaniu” internetowego świata przez stacje radiowe. To $z$ kolei pociąga za sobą konsekwencje w postaci przesunięcia akcentów medialnych - od jednej/jednego do wielu: platform, standardów, technologii oraz od pasywnego do aktywnego odbiorcy. Co istotne, jest to tendencja, której nadawcy radiowi nie mogą nie brać pod uwagę, stanowi ona bowiem wyznacznik dzisiejszych czasów. Także radio, by efektywnie odnaleźć się w tej rzeczywistości, musi dostosować się do takiego właśnie formatu (tak jak zrobił to z powodzeniem sektor prasy wysokonakładowej i opiniotwórczej), wykorzystując nowe media jako nośniki informacji i treści atrakcyjnej zarówno dla nadawcy radiowego, jak i odbiorcy takiej właśnie oferty. Wymaga to zmiany sposobu myślenia o pracy radiowej oraz o sytuacji komunikacyjnej: role "nadawcy" $i$ "odbiorcy" muszą z konieczności ulec redefinicji i zostać dostosowane do nowej sytuacji od- 
bioru. Procesy, o których mowa, postępują z dużą szybkością i są widoczne choćby w przypadku Polskiego Radia SA, które poszerza swoją ofertę o internetowe pozycje. Następuje tu zresztą interesujące zjawisko konwergencji mediów - radio przestaje być jedynie domeną tego, co odbiorca słyszy, lecz stało się dzięki Internetowi medium, które dekodujemy nie tylko słuchem, ale również wzrokiem czytając treści umieszczane na stronach przez nadawców. Drugim aspektem tego zagadnienia jest kwestia „ulotności” oferty radiowej - współczesna łatwość zapisu sprawia, że archiwum radiowe staje się łatwo dostępne także dla przeciętnych odbiorców, co w tradycyjnym modelu nadawczym nie było możliwe.

Praca Stanisława Jędrzejewskiego Radiofonia publiczna w Europie w erze cyfrowej to interesujący przykład rzetelnego wywodu naukowego, napisanego ciekawie, traktującego o ważkich problemach, zauważającego skomplikowane relacje, w jakie wchodzi współczesny nadawca radiowy, podkreślającego specyfikę medium radiowego, a przy tym - nieunikającego istotnych pytań o przyszłość. Wszystko to sprawia, że książka ta może trafić nie tylko do specjalistów zajmujących się mediami, ale także ma szansę zainteresować wszystkich miłośników radia - zarówno tych, którzy szukają w nim rozrywki, informacji, jak i tych, którzy cenią intymność radiowego kontaktu słuchacza z dziennikarzem prowadzącym program. Więź to wszak specyficzna, ulotna i oparta na swoistym napięciu między formą przekazu radiowego a treścią informacji, traktowanej w specyficzny sposób przez nadawcę publicznego, na którym skupia się autor.

Marek Jeziński

(Uniwersytet Mikołaja Kopernika w Toruniu) 